\title{
The prosodic and nonverbal deficiencies of French- and Finnish-speaking persons with Asperger Syndrome
}

\author{
Mari Lehtinen \\ Department of Romance Languages, University of Helsinki, Finland \\ https://doi.org/10.36505/ExLing-2008/02/0033/000092
}

\begin{abstract}
This paper briefly presents a research project directed towards the prosodic and nonverbal deficiencies of French- and Finnish-speaking persons with Asperger Syndrome (AS). AS is a form of high-functioning autism and it is characterized e.g. by qualitative impairment in social interaction and by stereotyped and restricted patterns of activities and interests. Though persons afflicted with AS generally have no significant delay in language acquisition, and their speech typically lacks significant abnormalities, the language use and the prosody of persons with AS is often atypical: people with AS often have a limited range of intonation, their speech may be overly fast, jerky or loud, and they also typically have abnormal nonverbal behaviours (such as eye contact, facial expressions, postures and gestures).
\end{abstract}

\section{Introduction}

This paper aims at providing a brief presentation of a post-doctoral research project that will be launched in the beginning of 2009. The project is directed towards the prosodic and nonverbal deficiencies of French- and Finnish-speaking persons afflicted with Asperger Syndrome (AS). AS is considered as a form of high-functioning autism (HFA) and it is characterized e.g. by qualitative impairment in social interaction and by stereotyped and restricted patterns of activities and interests (APA 2000). Though people with AS generally have no significant delay in language acquisition (APA 2000), and their speech typically lacks significant abnormalities, their language use and the prosody of speech are often atypical (Klin 2006): people with AS often have a limited range of intonation, their speech may be overly fast, jerky or loud. According to Partland and Klin (2006), people afflicted with AS also typically have abnormal nonverbal behaviours (such as eye contact, facial expressions, postures and gestures).

So far, the speech prosody and the nonverbal behaviors of people with As have been studied mainly in the fields of psychology, neurology and paediatrics. The project presented here aims at providing a linguistic study (including a phonetic perspective) contrasting the prosodic and nonverbal features of French- and Finnish-speaking people diagnosed with AS. In addition to the general contribution that a linguistic (and a phonetic) approach may bring to the field of AS, the fact of contrasting two unrelated and fundamentally different languages such as French and Finnish can be

ExLing 2008: Proceedings of 2nd Tutorial and Research Workshop on Experimental Linguistics, 25-27 August 2008, Athens, Greece 
expected to produce interesting results concerning the role of language- and culture-specific features in the development of speech and nonverbal behaviour of people with AS.

The data will consist of audiovisual material recorded from discussions where under 12-year-old French- and Finnish-speaking children are being diagnosed by a paediatrician specialised in AS.

Methodologically, the study will be based on conversation analysis (Sacks, Schegloff and Jefferson 1974; Hakulinen 1997; Sorjonen et al. 2006; Peräkylä 2004) and, more precisely, on the interactional approach to the study of prosody (Couper-Kuhlen and Selting 1996). The contextualization theory of Gumperz (1992) will also have a central role in the project: indeed, the prosodic and nonverbal features constituting the object of the study will be considered as "contextualization cues" in the sense of Gumperz.

\section{Background}

So far, the prosody of persons with AS has been studied mainly within the fields of psychology and neurology with the help of mismatch negativity $(\mathrm{MMN})$, which is a component of the event-related potential (ERP), arising from the electrical activity in the brain (Korpilahti et al. 2007; Kujala et al. 2005). The results of the MMN studies suggest that people with AS have problems to recognise affective prosody. It has also been shown that persons with AS have difficulties to produce affective prosodic patterns (Scott 1985). The speech of people with AS is often melodically monotonous, and it may also be overly fast, jerky or loud (Partland and Klin 2006). People afflicted with AS often have atypical nonverbal behaviours - such as eye contact, facial expressions, postures and gestures (Partland and Klin 2006) - and they may also have difficulties to recognise nonverbal signs of the interlocutor (Scott 1985). It has also been shown that it is more difficult for children afflicted with AS than for other children to use the linguistic context for the interpretation of a verbal message (Loukusa et al. 2007).

\section{Objectives}

This project is directed towards comparing the prosodic and nonverbal features characterising the interaction of French- and Finnish-speaking people with AS. The objective of the study is to find out in what measure the prosodic and nonverbal deficiencies of persons afflicted with AS depend on purely diagnostic factors, and what is the role of language- and culturespecific features in the manifestations of these features.

Choosing to contrast precisely French and Finnish is justified by at least four factors: 1) French and Finnish are unrelated languages (Indo-European vs. Uralic language); 2) there is no close contact between these languages; 3 ) 
they are spoken in rather different cultural environments; 4) the prosodic structures of these languages are completely different.

In addition to comparing the two languages, one of the goals of the project is to acquire new information concerning the connection (the cooperation / the lack of cooperation) between the prosodic and nonverbal means of communication used by people afflicted with AS.

\section{Data}

The data will consist of audiovisual (DVD) recordings from five French and five Finnish diagnostic discussions, the diagnostic result of which is positive. The informants will be 4-11-year old native French- and Finnish-speaking children who are being diagnosed by a paediatrician specialised in AS. Choosing children as informants is particularly interesting for the following reasons: 1) AS is typically diagnosed in 4-11-year-old children (Partland and Klin 2006); 2) the influence of experience and practise is less important in the case of children than in the case of adults.

As being five times more common for males than for females, most informants will be male. If possible, persons having been diagnosed with other neurological deviations (such as ADHD, AD, HD, Tourette syndrome or OCD) and/or being afflicted with mood disorders requiring medication (such as depression, anxiety or bipolar disorder) at the moment of the recorded discussion are preferably not chosen as informants, because the aforesaid states may affect the prosodic and nonverbal means of communication used by the person.

\section{References}

American Psychiatric Association (APA) 2000. Diagnostic and Statistical Manual of Mental Disorders. 4th edition, Text Revision, DSM-IV-TR. Arlington, American Psychiatric Association.

Couper-Kuhlen, E. and Selting, M. 1996. Towards an interactional perspective. In Couper-Kuhlen, E. and Selting, M. (eds.) 1996, Prosody in conversation. Interactional studies, 11-56. Cambridge, Cambridge University Press.

Danon-Boileau, L. and Morel, M.-A. 2007. Approche linguistique du discours autistique : quelques remarques. In Touati, B., Joly, F. and Laznik, M.-C. (eds.) 2007, Langage, voix et parole dans l'autisme, 335-340. Paris, PUF.

Di Cristo, A. 1998. Intonation in French. In Hirst, D. and Di Cristo, A. (eds.) 1998, Intonation Systems. A Survey of Twenty Languages, 195-218. Cambridge, Cambridge University Press.

Gumperz, J. J. 1992. Contextualization Revisited. In Auer, P. and Di Luzio, A. (eds.) 1992, The Contextualization of Language, 39-53. Amsterdam/Philadelphia, John Benjamins.

Hakulinen, A. 1997. Vuorottelujäsennys. In Tainio, L. (ed.) 1997, Keskustelunanalyysin perusteet, 32-55. Tampere, Vastapaino. 
Korpilahti, P., Jansson-Verkasalo, E., Mattila, M.-L., Kuusikko, S., Suominen, K., Rytky, S. Pauls, D.L. and Moilanen, I. 2007. Processing of affective speech prosody is impaired in Asperger syndrome. Journal of Autism and Developmental Disorders 37(8), 1539-1549.

Kujala, T., Lepistö, T., Nieminen-von Wendt, T. Näätänen, P. and Näätänen, R. 2005. Neurophysiological evidence for cortical discrimination impairment of prosody in Asperger syndrome. Neuroscience Letters 383(3), 260-265.

Loukusa, S., Leinonen, E., Kuusikko, S., Jussila, K., Mattila, M.-L., Ryder, N., Ebeling, H. and Moilanen, I. 2007. Use of context in pragmatic language comprehension by children with Asperger syndrome or high-functioning autism. Journal of Autism and Developmental Disorders 37(6), 1049-1059.

Morel, M.-A. and Danon-Boileau, L. 1998. Grammaire de l'intonation. L'exemple du français oral. Paris, Ophrys.

Nieminen-vonWendt, T. 2004. On the origins and diagnosis of Asperger syndrome. A clinical, neuroimaging and genetic study. Academic dissertation. University of Helsinki. Helsinki, Yliopistopaino.

Partland, J. and Klin, A. 2006. Asperger's syndrome. Adolescent Medicine Clinics 17(3), 771-88.

Peräkylä, A. 2004. Potilaan rooli psykoanalyysissä ja yleisläkärin vastaanotolla. In Alapuro, R. and Arminen, I. (eds.) 2004, Vertailevan tutkimuksen ulottuvuuksia, 245-258. Helsinki, WSOY.

Sacks, H., Schegloff, E. and Jefferson, G. 1974. A simplest systematics for the organization of turn-taking for conversation. Language 50, 696-735.

Scott.D.-W. 1985. Asperger's syndrome and non-verbal communication: a pilot study. Psychological Medicine 15(3), 683-687.

Sorjonen, M.-L., Raevaara L., Haakana, M., Tammi, T. and Peräkylä, A. 2006. Lifestyle discussions in medical interviews. In Heritage, J. and Maynard, D. (eds.) 2006, Communication in Medical Care. Interaction between primary care physicians and patients, 340-378. Cambridge, Cambridge University Press. 